\title{
THE IMPLEMENTATION OF SCIENCE, TECHNOLOGY, ENGINEERING, AND MATHEMATICS (STEM) LEARNING TO IMPROVE BASIC ASKING SKILLS AND LEARNING ACHIEVEMENTS STUDENTS OF ELEMENTARY SCHOOL
}

\author{
IlmaAulia Mufidah \\ Universitas Muhammadiyah Purwokerto, Jawa Tengah, Indonesia \\ Email: ilmaaulia99@gmail.com \\ Badarudin \\ Universitas Muhammadiyah Purwokerto, Jawa Tengah, Indonesia \\ Email: badarudinbdg@gmail.com

\section{Pratik Hari Yuwono} \\ Universitas Muhammadiyah Purwokerto, Jawa Tengah, Indonesia \\ Email: praktikyuwono@gmail.com
}

DOI: 10.35445/alishlah.V11.i2.133

Accepted: June $24^{\text {th }}, 2019$. Approved: November $13^{\text {rd }}, 2019$. Published: December $30^{\text {th }}, 2019$

\begin{abstract}
This study aims to improve basic questioning skills and student achievement through learning based on science, technology, engineering, and mathematics (STEM). This is a classroom action research that carried out in two cycles, each cycle consisting of two meetings. The subjects of this research were 30 fourth grade students. The data collection tool used evaluation tests, observation sheets for teacher and student activities, and observation sheets for students' basic questioning skills. The results showed that the application of STEM learning can improve students' basic questioning skills from the first cycle with an average of 2.48 to 4.45 in the second cycle. Students' mastery learning presentation also increased every cycle, from $70.44 \%$ to $96.66 \%$ for science lessons and $78.94 \%$ to $96.66 \%$ for Indonesian language lessons. The application of STEM-based learning gives good results and learning activities take place actively and pleasantly.
\end{abstract}

Keywords: Basic Questions, Learning Achievements, and STEM Learning 
Al-Ishlah: Jurnal Pendidikan - ISSN: 2087-9490 (p); 2597-940X (e)

Vol. 11, No. 2 (2019)

\title{
PENERAPAN PEMBELAJARAN BERBASIS SCIENCE, TECHNOLOGY, ENGINEERING, AND MATHEMATICS (STEM) UNTUK MENINGKATKAN KETERAMPILAN BERTANYA DASAR DAN PRESTASI BELAJAR PESERTA DIDIK SEKOLAH DASAR
}

\begin{abstract}
Abstrak
Penelitian ini bertujuan untuk meningkatkan keterampilan bertanya dasar dan prestasi belajar peserta didik melalui pembelajaran berbasis science, technology, engineering, and mathematics (STEM). Penelitian ini adalah penelitian tindakan kelas yang dilaksanakan dalam dua siklus, masing-masing siklus terdiri atas dua pertemuan. Subjek penelitian ini adalah peserta didik kelas IV yang berjumlah 30 orang. Alat pengumpulan data menggunakan tes evaluasi, lembar observasi aktivitas guru dan peserta didik, serta lembar observasi keterampilan bertanya dasar peserta didik. Hasil penelitian menunjukkan bahwa penerapan pembelajaran STEM dapat meningkatkan keterampilan bertanya dasar peserta didik dari siklus I dengan perolehan rata-rata 2,48 menjadi 4,45 pada siklus II. Presentasi ketuntasan belajar peserta didik juga meningkat setiap siklusnya, dari 70,44\% menjadi 96,66\% untuk pelajaran IPA dan 78,94\% menjadi 96,66\% untuk pelajaran Bahasa Indonesia. Penerapan pembelajaran berbasis STEM memberikan hasil yang baik serta kegiatan belajar berlangsung dengan aktif dan menyenangkan.
\end{abstract}

Kata Kunci: Bertanya Dasar, Prestasi Belajar, Pembelajaran STEM

\section{PENDAHULUAN}

Kegiatan pembelajaran tidak terlepas dari kegiatan tanya jawab, baik antara peserta didik dengan guru maupun antarpeserta didik. Keterampilan bertanya cukup penting dimiliki oleh peserta didik karena dengan bertanya mereka dapat menerima materi dengan baik. Astuti (2015: 11) menyatakan bahwa keterampilan bertanya adalah cara penyampaian suatu pelajaran melalui interaksi dua arah, yaitu dari guru kepada peserta didik dan dari peserta didik kepada guru, agar diperoleh jawaban kepastian materi melalui jawaban lisan guru atau peserta didik. Rendahnya keterampilan bertanya peserta didik dapat menyebabkan peserta didik salah konsep maupun tidak memahami konsep materi yang telah dijelaskan guru dan dapat berpengaruh terhadap prestasi belajar peserta didik.

Data yang diperoleh dari hasil observasi yang telah dilakukan pada awal kegiatan pembelajaran berlangsung menunjukkan keaktifan peserta didik dalam bertanya masih sangat kurang. Peserta didik jarang sekali mengajukan pertanyaan 
Al-Ishlah: Jurnal Pendidikan - ISSN: 2087-9490 (p); 2597-940X (e)

Vol. 11, No. 2 (2019)

kepada guru selama proses pembelajaran berlangsung. Apabila guru mengajukan pertanyaan, hampir seluruh peserta didik tidak berani mengacungkan tangannya untuk menjawab. Apabila diberi kesempatan untuk bertanya, peserta didik jarang memanfaatkannya. Guru masih belum mampu membuat peserta didik aktif bertanya. Kegiatan pembelajaran masih didominasi oleh guru dengan cara menjelaskan materi melalui ceramah. Permasalahan tersebut juga berdampak pada prestasi belajar peserta didik. Prestasi belajar peserta didik tergolong rendah. Hal ini dibuktikan dengan hasil penilaian akhir semester (PAS) dari 30 peserta didik. Dari PAS ketiga puluh peserta didik tersebut, hanya 11 orang (37\%) yang tuntas dalam pelajaran Bahasa Indonesia dan 18 orang $(60 \%)$ yang tuntas dalam pelajaran IPA.

Berdasarkan beberapa penelitian sebelumnya, seperti penelitian yang dilakukan oleh Astuti (2015), Elviah (2017), dan Sofwan (2016), tampak bahwasannya keterampilan bertanya itu sangat penting dimiliki oleh peserta didik. Hal tersebut bermaksud agar mereka mampu menerima materi dengan baik dan dapat mengemukakan pendapat walaupun pertanyaan yang diajukan masih dalam konteks bertanya dasar. Bertanya termasuk salah satu keterampilan yang harus dimiliki oleh peserta didik dan merupakan kegiatan penting yang harus ada dalam suatu kegiatan pembelajaran, karena untuk menjawab ketidaktahuan peserta didik terhadap suatu konsep yang sedang dipelajari, ia harus bertanya.

Pada hakikatnya, dengan bertanya kita akan mengetahui dan mendapatkan informasi tentang apa saja yang ingin diketahui. Terampil bertanya akan membantu peserta didik lebih sempurna dalam menerima informasi. Peserta didik kelas IV seharusnya sudah mampu mengajukan pertanyaan dalam proses pembelajaran. Hal ini sejalan dengan pendapat Sofwan (2016: 30) yang menyatakan bahwa peserta didik dengan kisaran umur 6-12 tahun memiliki pola piker yang sudah mengarah ke semi konkret dan intelegensi yang sudah berkembang. Perkembangan kognitif yang baik dapat membuat peserta didik mampu mengajukan pertanyaan tetapi masih dalam konteks bertanya dasar. Simanjuntak (2016: 30-31) berpendapat bahwa melalui kegiatan bertanya dasar, peserta didik dirangsang untuk dapat menyelesaikan masalah dengan prinsipprinsip berpikir ilmiah yang mampu meningkatkan nalar.

Tujuan dari keterampilan bertanya dasar yaitu dapat meningkatkan rasa ingin tahu, mendorong untuk dapat mengungkapkan pendapat, meningkatkan pemahaman materi, dan menghidupkan aktivitas kelas. Peserta didik perlu bertanya dengan baik agar guru memahami hal yang ditanyakan. Untuk, itu peserta didik perlu memahami teknik bertanya dasar yang baik. Teknik tersebut menunjukkan indikator keterampilan bertanya peserta didik. Zaifbio dalam Astuti (2015: 14) menyebutkan indikator keterampilan bertanya peserta didik meliputi substansi pertanyaan, frekuensi pertanyaan dalam satu jam pelajaran, bahasa, 
Al-Ishlah: Jurnal Pendidikan - ISSN: 2087-9490 (p); 2597-940X (e)

Vol. 11, No. 2 (2019)

suara, dan kesopanan. Sementara, menurut Elviah (2017: 64-65), aspek penilaian dalam keterampilan bertanya dasar peserta didik antara lain ketepatan, keringkasan, kejelasan, relevansi, dan kualitas pertanyaan, serta keberanian bertanya.

Belajar dapat mengubah seseorang dari yang tidak tahu menjadi tahu. Perubahan tersebut melalui proses yang bermakna dan juga dilakukan dengan sadar. Mulyasa (2014: 189) berpendapat bahwa prestasi belajar adalah hasil yang diperoleh seseorang setelah menempuh kegiatan belajar, sedangkan Sudijono (2012: 434) menyatakan bahwa prestasi dijadikan sebagai salah satu bahan pertimbangan dalam penentuan nilai akhir, sebab prestasi atau pencapaian peserta didik dilambangkan dengan nilai-nilai. Berdasarkan penjelasan tersebut dapat disimpulkan bahwa prestasi belajar merupakan hasil yang telah dicapai peserta didik dalam kegiatan belajar yang diketahui melalui kegiatan evaluasi.

STEM telah banyak diterapkan dalam kegiatan pembelajaran. Sukmana (2017: 192-193) menyatakan bahwa science, technology, engineering, and mathematics atau disingkat STEM merupakan sebuah pendekatan pembelajaran yang populer di tingkat dunia yang efektif dalam menerapkan pembelajaran tematik integratif karena menggabungkan empat bidang pokok Pendidikan, yaitu ilmu pengetahuan, teknologi, matematika, dan engineering. Pembelajaran STEM mengintegrasikan empat bidang ilmu yaitu sains, teknologi, teknik, dan matematika.

Penelitian yang dilakukan oleh Falentina (2018) dan Sukmana (2017) memperlihatkan bahwa pembelajaran berbasis STEM dapat meningkatkan minat belajar peserta didik, terlebih jika penggunaan media seperti mobil bertenaga angin yang dapat melibatkan peran aktif peserta didik dalam proses pembelajaran. Hal tersebut tentunya secara tidak langsung dapat meningkatkan prestasi belajar karena peserta didik terlibat secara langsung dalam proses belajar yang bermakna dan menyenangkan. Penelitian yang dilakukan oleh English (2015) juga terkait dengan pengaruh pembelajaran STEM yang dapat membuat peserta didik kelas IV berpikir kritis, inovatif, dan terampil membuat pesawat terbang dengan mendesain ulang pesawat berdasar pendekatan STEM. Hasil yang didapatkan yaitu peserta didik dapat mengaplikasikan dan menghubungkan proyek dengan komponen STEM. Berdasarkan beberapa penelitian yang telah dilakukan, diketahui bahwa pembelajaran STEM dapat meningkatkan prestasi akademik dan nonakademik peserta didik dan mampu meningkatkan penguasaan dan pengaplikasian pengetahuan untuk memecahkan masalah, serta mendorong peserta didik untuk menciptakan sesuatu yang baru.

Pembelajaran STEM memberikan manfaat yang cukup besar bagi peserta didik. Morrison dalam Winarni (2016: 977) menyatakan bahwa manfaat STEM ialah membuat peserta didik menjadi pemecah masalah, penemu, inovator, 
Al-Ishlah: Jurnal Pendidikan - ISSN: 2087-9490 (p); 2597-940X (e)

Vol. 11, No. 2 (2019)

mandiri, pemikir yang logis, melek teknologi, penghubung budaya dan sejarah dengan pendidikan, dan penghubung pendidikan STEM dengan dunia kerja.

Tujuan pembelajaran STEM dalam dunia pendidikan sejalan dengan tuntutan pendidikan abad ke-21. Bybee dalam Jauhariyyah (2017: 432) menyatakan bahwa tujuan STEM yaitu peserta didik memiliki literasi sains dan teknologi melalui aktivitas membaca, menulis, mengamati, serta melakukan sains, serta mampu mengembangkan kompetensi yang telah dimiliki untuk diterapkan dalam menghadapi permasalahan dalam kehidupan sehari-hari yang terkait bidang ilmu STEM. Sementara, secara garis besar Kelley (2016: 3) berpendapat bahwa pendidikan STEM terintegrasi sebagai pendekatan dalam pengajaran konten STEM yang terikat oleh praktik dengan tujuan meningkatkan pembelajaran serta melatih peserta didik dalam menerapkan pengetahuan untuk membuat desain sebagai bentuk pemecahan masalah.

Terdapat tiga cara dalam menerapkan pembelajaran berbasis STEM. Roberts (2012: 111-114) telah mengembangkan tiga pendekatan pembelajaran STEM yang berbeda. Ketiga pendekatan tersebut merupakan cara menerapkan pembelajaran berbasis STEM dalam proses/kegiatan pembelajaran yang meliputi pendekatan silo, tertanam, dan terpadu. Pendekatan yang digunakan dalam penelitian ini adalah pendekatan terpadu. Pendekatan terpadu mengajarkan keempat bidang STEM sebagai satu subjek yang menghubungkan materi dari berbagai bidang dengan keterampilan berpikir kritis, pemecahan masalah, dan pengetahuan untuk mencapai suatu kesimpulan. Pendekatan terpadu adalah pendekatan terbaik untuk pembelajaran STEM yang diharapkan dapat meningkatkan minat pada bidang STEM terutama jika dimulai sejak peserta didik masih muda.

Proses pembelajaran STEM dalam membimbing peserta didik terdiri atas lima langkah. Setiap langkah bertujuan untuk mencapai proses secara spesifik. Tahapan dalam proses pembelajaran STEM yang efektif menurut Laboy-Rush dalam Jauhariyyah (2017: 434-435) yaitu sebagai berikut. Tahap pertama adalah reflection dengan cara membawa peserta didik ke dalam konteks masalah dan memberikan inspirasi agar dapat segera mulai menyelidiki/investigasi. Tahap kedua adalah research yang merupakan bentuk penelitian. Tahap ketiga adalah discovery, yaitu tahap penemuan, umumnya melibatkan proses yang menjembatani research dan informasi ketika peserta didil mulai belajar mandiri dan menentukan hal yang belum diketahui. Tahap keempat adalah application yang tujuannya untuk menguji produk/solusi dalam memecahkan masalah. Tahap terakhir adalah communication, yaitu mengomunikasikan hasil penemuan antarteman maupun lingkup kelas.

Berdasarkan permasalahan yang ditemukan, faktor utama yang harus segera dicarikan solusinya adalah bagaimana cara meningkatkan keterampilan 
Al-Ishlah: Jurnal Pendidikan - ISSN: 2087-9490 (p); 2597-940X (e)

Vol. 11, No. 2 (2019)

bertanya dasar dan prestasi belajar peserta didik sehingga peserta didik tidak hanya mendengar, mencatat penjelasan guru, dan menjawab soal, tetapi juga mampu mengajukan pertanyaan, menyampaikan pendapat, menyimpulkan materi pelajaran, mengomunikasikan pesan pelajaran, serta mengerjakan lembar evaluasi dengan baik.

Peneliti berkolaborasi dengan guru kelas sepakat untuk menggunakan pembelajaran berbasis science, technology, engineering, and mathematics (STEM) dalam upaya meningkatkan keterampilan bertanya dasar dan prestasi belajar peserta didik. Pembelajaran berbasis STEM telah dipercaya efektif dalam menerapkan pembelajaran tematik integratif karena di dalam STEM digabungkan empat bidang pokok Pendidikan, yaitu ilmu pengetahuan, teknologi, teknik, dan matematika. Pembelajaran berbasis STEM dapat menunjang keterampilan abad ke-21 dan diketahui bahwa keterampilan tersebut sangat dibutuhkan perannya dalam dunia pendidikan.

\section{METODE PENELITIAN}

Jenis penelitian ini adalah penelitian tindakan kelas yang dilaksanakan di SDN 1 Karangkedawung pada Maret sampai dengan April 2019 dengan jumlah peserta didik 30 orang yang terdiri atas 12 perempuan dan 18 laki-laki. Penelitian ini dilakukan selama dua siklus. Setiap siklus terdiri atas dua pertemuan dengan tiap siklus meliputi tahapan dalam prosedur penelitian, yaitu perencanaan, pelaksanaan, pengamatan, dan refleksi. Teknik pengumpulan data menggunakan teknik tes dan nontes. Teknik tes berupa tes tertulis untuk pengumpulan data hasil evaluasi belajar, sedangkan teknik nontes berupa observasi, wawancara, dan dokumentasi.

Analisis data yang digunakan adalah analisis kualitatif dan kuantitatif. Pada setiap siklus dilakukan komparasi data untuk memastikan ada tidaknya peningkatan keterampilan bertanya dasar dan prestasi belajar peserta didik. Penilaian keterampilan bertanya dasar dan prestasi belajar peserta didik dilakukan dengan membandingkan nilai yang diperoleh peserta didik pada siklus I dan siklus II. Sebagai tolok ukur keberhasilan pelaksanaan PTK ini ditetapkan indikator keberhasilan sebagai berikut: 1) adanya peningkatan keterampilan bertanya dasar peserta didik dengan skor rata-ratanya mencapai > 3,4 s.d. 4,2 atau sekurangkurangnya $80 \%$ dari jumlah peserta didik masuk dalam kriteria baik; 2) adanya peningkatan prestasi belajar peserta didik dengan ketuntasan belajar mencapai nilai persentase $61-80 \%$ atau sekurang-kurangnya $80 \%$ dari jumlah peserta didik memenuhi KKM yang telah ditentukan. 
Al-Ishlah: Jurnal Pendidikan - ISSN: $2087-9490$ (p); 2597-940X (e)

Vol. 11, No. 2 (2019)

\section{HASIL DAN PEMBAHASAN}

Penelitian tindakan kelas ini didasarkan atas hasil penelitian yang telah dilakukan oleh peneliti. Melalui pembelajaran berbasis STEM, peserta didik memperoleh hasil berupa pengetahuan dan keterampilan yang meningkat dalam setiap tahapan pembelajaran. Peningkatan tersebut terjadi secara berkala dan berkesinambungan. Adapun hasil dan pembahasan dalam penelitian ini dapat dilihat sebagai berikut.

Kegiatan belajar bukan hanya untuk mendapatkan sebuah pengetahuan, tetapi juga keterampilan. Salah satu keterampilan yang dapat menunjang keberhasilan peserta didik dalam belajar yaitu keterampilan bertanya. Hal ini sejalan dengan pendapat Suprihatiningrum (2013: 15) bahwa belajar merupakan aktivitas mental dan psikis yang berlangsung dalam interaksi aktif dengan lingkungan dan menghasilkan perubahan dalam pengetahuan dan pemahaman, keterampilan, serta nilai-nilai dan sikap. Belajar yang sesungguhnya adalah suatu kegiatan yang dapat menghasilkan pengetahuan, keterampilan, perubahan tingkah laku, pengalaman yang baru, serta pembentukan karakter.

Pada penelitian ini, keterampilan bertanya dasar peserta didik meningkat karena pembelajaran STEM menuntut peserta didik menjadi pemecah masalah sehingga harus aktif dalam bertanya maupun kegiatan lainnya agar permasalahan dapat terselesaikan. Hal ini sejalan dengan pendapat Morrison dalam Winarni (2017: 977) yang menyatakan bahwa manfaat STEM ialah membuat peserta didik menjadi pemecah masalah, penemu, inovator, mampu mandiri, pemikir yang logis, melek teknologi, mampu menghubungkan budaya dan sejarahnya dengan pendidikan, dan mampu menghubungkan pendidikan STEM dengan dunia kerja.

Kegiatan pembelajaran yang dilakukan memberikan dampak positif bagi peserta didik. Contohnya, pada saat diskusi dalam mengerjakan lembar kerja peserta didik (LKPD), peserta didik dituntut untuk menjadi pemikir yang logis, penemu, pemecah masalah, mandiri, dan inovator. Contoh lain adalah pembuatan kincir angin, mobil balon (billon), dan jembatan dari sedotan yang dapat membuat peserta didik menjadi penemu, melek teknologi, pemikir yang logis, kreatif, serta pemecah masalah. Pada saat pembuatan proyek tersebut ada kemungkinan terjadinya kegagalan, maka peserta didik mau tidak mau harus menyelesaikan masalah itu, baik dengan cara diskusi maupun bertanya, supaya percobaan yang dilakukan berhasil.

Peningkatan keterampilan bertanya dasar peserta didik terlihat dari hasil observasi yang telah dilakukan pada setiap pertemuan dalam dua siklus yang telah dilaksanakan. Peningkatan hasil observasi rata-rata tiap indikator keterampilan 
Al-Ishlah: Jurnal Pendidikan - ISSN: 2087-9490 (p); 2597-940X (e)

Vol. 11, No. 2 (2019)

bertanya dasar peserta didik dalam setiap pertemuannya dapat dilihat dalam tabel berikut.

Tabel 1 Peningkatan Hasil Observasi Keterampilan Bertanya Dasar Peserta Didik

\begin{tabular}{|c|c|c|c|c|}
\hline \multirow{2}{*}{$\begin{array}{c}\text { Indikator Keterampilan Bertanya } \\
\text { Dasar }\end{array}$} & \multicolumn{2}{|c|}{ Siklus I } & \multicolumn{2}{|c|}{ Siklus II } \\
\hline & P1 & $\mathbf{P 2}$ & P1 & $\mathbf{P 2}$ \\
\hline $\begin{array}{l}\text { Isi pertanyaan sesuai dengan materi yang } \\
\text { sedang dipelajari }\end{array}$ & 2,00 & 2,92 & 4,00 & 4,89 \\
\hline $\begin{array}{l}\text { Pertanyaan diajukan secara singkat, jelas, } \\
\text { dan logis }\end{array}$ & 2,10 & 3,21 & 4,30 & 4,82 \\
\hline $\begin{array}{l}\text { Pertanyaan diajukan dengan menggunakan } \\
\text { bahasa yang baik dan benar }\end{array}$ & 2,10 & 3,25 & 4,46 & 5,00 \\
\hline $\begin{array}{l}\text { Pertanyaan diajukan dengan suara lantang, } \\
\text { vokal jelas, lancar, dan tenang }\end{array}$ & 1,82 & 3,14 & 4,16 & 4,41 \\
\hline Bertanya tanpa ada paksaan dari orang lain & 2,06 & 3,10 & 4,40 & 5,00 \\
\hline $\begin{array}{l}\text { Menatap wajah guru atau teman ketika } \\
\text { bertanya }\end{array}$ & 2,10 & 3,28 & 4,43 & 4,96 \\
\hline $\begin{array}{l}\text { Mengacungkan tangan ke atas ketika } \\
\text { bertanya }\end{array}$ & 1,75 & 2,96 & 4,46 & 4,89 \\
\hline $\begin{array}{l}\text { Mengajukan pertanyaan dengan } \\
\text { menggunakan tutur kata dan perilaku yang } \\
\text { sopan }\end{array}$ & 1,96 & 3,28 & 4,46 & 5,00 \\
\hline $\begin{array}{l}\text { Frekuensi pertanyaan selama kegiatan } \\
\text { pembelajaran }\end{array}$ & 1,41 & 2,32 & 2,80 & 3,62 \\
\hline Jumlah rata-rata & 17,3 & 27,46 & 37,47 & 42,49 \\
\hline Rata-rata tiap siklus & & \multicolumn{2}{|c|}{4,45} \\
\hline Kriteria & \multicolumn{2}{|c|}{ Kurang } & \multicolumn{2}{|c|}{ Sangat Baik } \\
\hline \multicolumn{5}{|l|}{ Keterangan: } \\
\hline \multicolumn{5}{|l|}{ P1: Pertemuan 1} \\
\hline P2: Pertemuan 2 & & & & \\
\hline
\end{tabular}

Pembelajaran berbasis STEM dapat menciptakan suasana kelas yang lebih hidup. Selalu ada interaksi antara guru dan peserta didik yang dapat dilihat ketika sedang melaksanakan diskusi dalam memecahkan suatu masalah. Peserta didik sudah berani mengemukakan pendapat dan aktif bertanya dalam proses pembelajaran, walaupun pada pertemuan awal masih banyak peserta didik yang pasif. Namun, seiring dengan perbaikan dan bimbingan yang dilakukan, aktivitas peserta didik dalam kegiatan pembelajaran membaik. Peserta didik juga sudah berani bertanya kepada guru terkait materi maupun teknis yang belum dipahami ketika melakukan suatu praktik STEM. 
Al-Ishlah: Jurnal Pendidikan - ISSN: 2087-9490 (p); 2597-940X (e)

Vol. 11, No. 2 (2019)

Meningkatnya keterampilan bertanya dasar peserta didik pada siklus I ke siklus II juga dipengaruhi oleh faktor aktivitas guru yang setiap pembelajaran selalu melakukan perbaikan. Hal ini juga menyebabkan aktivitas guru pada setiap siklus mengalami peningkatan. Persentase aktivitas guru mengalami peningkatan dari 92,54\% dengan kriteria sangat baik menjadi 99,02\% dengan kriteria sangat baik. Kenaikan siklus I ke siklus II yaitu sebesar 6,48\%.

Hasil prestasi belajar diukur dengan menggunakan soal evaluasi yang diberikan pada setiap akhir pertemuan. Hasil prestasi belajar pada siklus I dan siklus II dapat dilihat pada tabel berikut.

Tabel 2 Hasil Prestasi Belajar Peserta Didik Siklus I dan Siklus II

\begin{tabular}{|c|c|c|c|c|c|}
\hline \multirow{2}{*}{ No } & \multirow{2}{*}{ Uraian } & \multicolumn{2}{|c|}{ Siklus I } & \multicolumn{2}{|c|}{ Siklus II } \\
\hline & & $\mathbf{P 1}$ & $\mathbf{P 2}$ & $\mathbf{P 1}$ & $\mathbf{P 2}$ \\
\hline \multicolumn{6}{|c|}{ Ilmu Pengetahuan Alam (IPA) } \\
\hline 1 & Jumlah Peserta Didik & 29 & 28 & 30 & 29 \\
\hline 2 & KKM & 62 & 62 & 62 & 62 \\
\hline 3 & $\begin{array}{l}\text { Jumlah Peserta Didik } \\
\text { Tuntas }\end{array}$ & 16 & 24 & 28 & 29 \\
\hline 4 & $\begin{array}{l}\text { Jumlah Peserta Didik Tidak } \\
\text { Tuntas }\end{array}$ & 13 & 4 & 2 & - \\
\hline 5 & Rata-rata Per Siklus & \multicolumn{2}{|c|}{70,91} & \multicolumn{2}{|c|}{89,25} \\
\hline 6 & $\begin{array}{l}\text { Presentase Ketuntasan Per } \\
\text { Pertemuan }\end{array}$ & \multicolumn{2}{|c|}{$55,17 \%$} & \multicolumn{2}{|c|}{$85,71 \%$} \\
\hline 7 & Persentase Ketuntasan & \multicolumn{2}{|c|}{$70,44 \%$} & \multicolumn{2}{|c|}{$96,66 \%$} \\
\hline \multicolumn{6}{|c|}{ Bahasa Indonesia } \\
\hline 1 & Jumlah Peserta Didik & 29 & 28 & 30 & 29 \\
\hline 2 & KKM & 65 & 65 & 65 & 65 \\
\hline 3 & $\begin{array}{l}\text { Jumlah Peserta Didik } \\
\text { Tuntas }\end{array}$ & 23 & 22 & 28 & 29 \\
\hline 4 & $\begin{array}{l}\text { Jumlah Peserta Didik Tidak } \\
\text { Tuntas }\end{array}$ & 6 & 6 & 2 & - \\
\hline 5 & Rata-rata Per Siklus & \multicolumn{2}{|c|}{74,81} & \multicolumn{2}{|c|}{90,77} \\
\hline 6 & $\begin{array}{l}\text { Presentase Ketuntasan Per } \\
\text { Pertemuan }\end{array}$ & \multicolumn{2}{|c|}{$79,31 \%$} & \multicolumn{2}{|c|}{$78,57 \%$} \\
\hline 7 & Persentase Ketuntasan & \multicolumn{2}{|c|}{$\mathbf{7 8 , 9 4 \%}$} & \multicolumn{2}{|c|}{$96,66 \%$} \\
\hline \multicolumn{6}{|c|}{ Keterangan: } \\
\hline \multicolumn{6}{|c|}{ P1: Pertemuan 1} \\
\hline P2: Pel & muan 2 & & & & \\
\hline
\end{tabular}


Al-Ishlah: Jurnal Pendidikan - ISSN: 2087-949o (p); 2597-940X (e)

Vol. 11, No. 2 (2019)

Peningkatan hasil belajar pada siklus I dan siklus II dapat terlihat pada diagram di bawah ini.

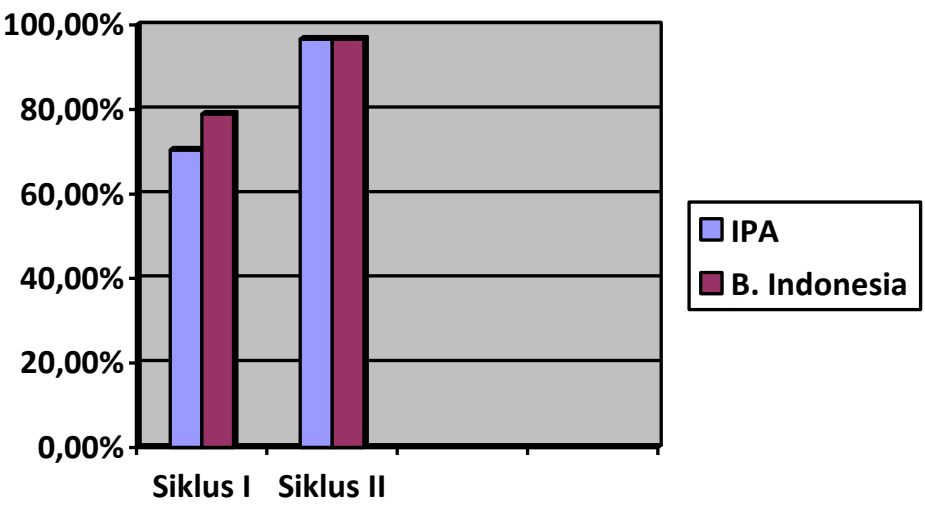

\section{Gambar 1 Diagram peningkatan hasil prestasi belajar peserta didik}

Berdasarkan evaluasi yang dikerjakan peserta didik, setiap siklusnya mengalami kenaikan. Hal ini tentu tidak terlepas dari peran guru dan peserta didik yang telah melaksanakan kegiatan pembelajaran dengan baik sehingga peserta didik dapat memaknai dengan baik setiap materi yang disampaikan oleh guru. Selain itu, peserta didik juga mampu mengerjakan lembar evaluasi dengan baik yang menyebabkan prestasi belajar meningkat.

Kegiatan yang dilakukan dalam pembelajaran STEM berupa membaca, mengenal masalah, mencari informasi, diskusi, menguji solusi, dan menyampaikan hasil diskusi. Adapun produk yang dibuat peserta didik dalam penelitian ini yaitu kincir angin, billon, jembatan dari sedotan, serta kegiatan lain yang berkaitan dengan materi. Melalui kegiatan tersebut, peserta didik akan lebih memahami dan mengingat materi karena kegiatan yang dilakukan secara langsung oleh peserta didik akan membuat pembelajaran lebih berkesan dan bermakna. Permanasari (2016: 29) menyatakan bahwa penerapan STEM cocok digunakan dalam pembelajaran sains karena dapat melatih peserta didik dalam menerapkan pengetahuan untuk membuat desain sebagai bentuk pemecahan masalah dengan memanfaatkan teknologi. Hal tersebut berkaitan dengan penelitian ini karena dalam penelitian ini peserta didik dituntut untuk membuat suatu produk dan melakukan percobaan sains guna memecahkan masalah dengan pendekatan STEM. Peserta didik pun terlibat aktif dalam pembelajaran sehingga mudah menerima materi dan baik dalam mengerjakan lembar evaluasi.

Meningkatnya prestasi belajar peserta didik juga dipengaruhi oleh aktivitas dari peserta didik itu. Pengamatan aktivitas peserta didik disesuaikan dengan 
Al-Ishlah: Jurnal Pendidikan - ISSN: 2087-9490 (p); 2597-940X (e)

Vol. 11, No. 2 (2019)

kegiatan pembelajaran yang dilakukan dan tahapan dalam pembelajaran berbasis STEM. Berdasarkan hasil observasi, dapat diketahui bahwa telah terjadi peningkatan aktivitas peserta didik dari siklus I sampai siklus II. Peningkatan aktivitas peserta didik dari siklus I sebesar 78,34\% meningkat pada siklus II menjadi $89,14 \%$.

Berdasarkan hasil tersebut, dapat dikatakan bahwa penggunaan pembelajaran berbasis STEM pada tema 8 "Daerah Tempat Tinggalku" di kelas IV dapat meningkatkan keterampilan bertanya dasar dan prestasi belajar peserta didik. Temuan yang peneliti dapatkan selama penelitian yaitu dengan adanya pemberian kesempatan seluas-luasnya kepada peserta didik untuk menjawab dan mengajukan pertanyaan serta memberi tanggapan dapat membuat peserta didik merasa lebih dihargai dan percaya diri. Selain itu, pembelajaran berbasis STEM dirasa cukup strategis untuk diterapkan dalam pembelajaran dengan menggunakan Kurikulum 2013 dan STEM juga diharapkan dapat menunjang keterampilan abad ke-21 yang harus dimiliki oleh peserta didik. Namun demikian, guru dituntut untuk terampil dalam merancang dan melaksanakan kegiatan pembelajaran yang juga harus disesuaikan dengan kebutuhan peserta didik.

\section{SIMPULAN}

Pembelajaran berbasis science, technology, engineering, and mathematics (STEM) dapat meningkatkan keterampilan bertanya dasar dan prestasi belajar peserta didik. Peserta didik dengan kriteria sangat baik sudah mencapai $80 \%$ dari total peserta didik dan sudah mencapai indikator keberhasilan dalam penelitian ini. Hal ini terbukti dengan adanya peningkatan rata-rata skor keterampilan bertanya dasar dari 2,48 dengan kriteria kurang menjadi 4,45 dengan kriteria sangat baik. Selain itu, persentase ketuntasan belajar peserta didik juga meningkat dari $70,44 \%$ menjadi $96,66 \%$ pada pelajaran IPA dan dari 78,94\% menjadi 96,66\% pada pelajaran Bahasa Indonesia. Melalui pembelajaran STEM, peserta didik aktif untuk bertanya dan belajar karena pembelajaran yang dilakukan menyenangkan dan bermakna yang membuat mereka menjadi penemu, individu yang kreatif, dan pemecah masalah. Peningkatan ini juga terjadi karena peran guru dan peserta didik dalam setiap siklus mengalami peningkatan melalui perbaikanperbaikan yang telah dilakukan. 
Al-Ishlah: Jurnal Pendidikan - ISSN: 2087-9490 (p); 2597-940X (e)

Vol. 11, No. 2 (2019)

\section{DAFTAR PUSTAKA}

Astuti, M. S. (2015). Peningkatan Keterampilan Bertanya dan Hasil Belajar Peserta didik Kelas 2 SDN Slungkep 03 Menggunakan Model Discovery Learning. Scholaria. 5 (1), 10-23.

Elviah. (2017). Meningkatkan Kemampuan Bertanya Dasar Siswa dengan Menggunakan Model Discovery Learning Di Kelas III B SDN 44 Jambi. Jurnal Pendidikan Tematik Dikdas Universitas Jambi. 2 (1), 60-71.

English, L.D \& Donna T.K. (2015). STEM Learning Through Engineering Design: Fourth-Grade Students' Investigation In Aerospace. International Journal of STEM Education. 1-18.

Falentina, C.T., Dindin A.M.L., dan Edi H.M. (2018). Mobil Bertenaga Angin: Media Berbasis STEM untuk Siswa Kelas IV Sekolah Dasar. Pedadidaktika: Jurnal Ilmiah Pendidikan Guru Sekolah Dasar. 5 (3), 152-162.

Jauhariyyah, F. R., Hadi S., dan Ibrohim. (2017). Science, Technology, Engineering and Mathematics Project Based Learning (STEM-PjBL) pada Pembelajaran Sains. Pros. Semnas Pendidikan IPA Pascasarjana UM. 2, 432-436.

Kelley, T.R \& Knowles, J.G. (2016). A Conceptual Framework for Integrated STEM Education. International Journal of STEM Education. Springer.

Mulyasa, H.E. (2014). Pengembangan dan Implementasi Kurikulum 2013. Bandung: Remaja Rosdakarya.

Permanasari, A. (2016). STEM Education: Inovasi dalam Pembelajaran Sains. Prosiding Seminar Nasional Pendidikan Sains. 23-34.

Roberts, A \& Cantu, D. (2012). Applying STEM Instructional Strategies to Design and Technology Curriculum. Norfolk, VA, USA: Department of STEM Education and Proffesional Studies Old Dominion University.

Simanjuntak, E.B \& Switri I.P. (2016). Peningkatan Keterampilan Bertanya Peserta didik pada Mata Pelajaran Bahasa Indonesia dengan Menggunakan Strategi Probing Prompting Learning di Kelas IV SD 
Al-Ishlah: Jurnal Pendidikan - ISSN: 2087-9490 (p); 2597-940X (e)

Vol. 11, No. 2 (2019)

Negeri 101767 Tembung T.A 2015/2016. Jurnal Handayani. 5 (1), 3038 .

Sofwan, M. (2016). Meningkatkan Kemampuan Bertanya Dasar Peserta didik dengan Menggunakan Model Discovery Learning di Kelas III B SDN 64/1 Muara Bulian. Jurnal Pendidikan Tematik Dikdas Universitas Jambi. 1 (1), 29-36.

Sudijono, A. (2012). Pengantar Evaluasi Pendidikan. Jakarta: RajaGrafindo Persada.

Sukmana, R.W. (2017). Pendekatan Science, Technology, Engineering And Mathematics (STEM) Sebagai Alternatif dalam Mengembangkan Minat Belajar Peserta Didik Sekolah Dasar. Jurnal Ilmiah Pendidikan Dasar. 2 (2), 191-199.

Suprihatiningrum, J. (2013). Strategi Pembelajaran. Jogjakarta: Ar-Ruzz Media.

Winarni, J., Siti Z., \& Soepriono K.H. (2016). STEM: Apa, Mengapa, dan Bagaimana. Pros. Semnas Pendidikan Dasar Pendidikan IPA Pascasarjana UM. 1, 976-984. 